\title{
sciforum
}

Proceeding Paper

\section{Characterization, Classification, Dry High Intensity Magnetic Separation (DHIMS) and Re-Grinding Techniques to Improve the Mineral Performance of a Sn-Ta-Nb Mineral Concentrate}

\author{
Jennire Nava ${ }^{1 . *}$, Teresa Llorens ${ }^{1}$, Juan Menéndez-Aguado ${ }^{2}$ \\ 1 Strategic Minerals Spain, Ctra/ OU-0901 Km 14, Penouta Mine, Viana do Bolo, 32558, Ourense, Galicia, \\ Spain; tllorens@strategicminerals.com \\ 2 Escuela Politécnica de Mieres, Universidad de Oviedo, 33600 Oviedo, Spain; maguado@uniovi.es \\ * Correspondence: jvanessanavar@gmail.com
}

Received: 28/09/2020; Accepted: 01/10/2020; Published: 16/11/2020

\begin{abstract}
Ta}$ and $\mathrm{Nb}$ are considered critical raw materials; due to their properties and potential applications in wide sectors. This study deals with $\mathrm{Sn}-\mathrm{Ta}-\mathrm{Nb}$ minerals from the Penouta mine (Orense, Spain), the only active mine in Europe producing tantalum minerals. These are obtained from mining wastes accumulated during old mining jobs in tailing ponds. The industrial processing flowsheet is based on successive gravimetric stages followed by low intensity magnetic separation to reduce ferromagnetic contaminants. $\mathrm{Sn}-\mathrm{Ta}-\mathrm{Nb}$ concentrate, with grades between $35-45 \% \mathrm{Sn}$ and $4-7 \% \mathrm{Ta}_{2} \mathrm{O}_{5}$ and $\mathrm{Nb}_{2} \mathrm{O}_{5}$, is obtained in this stage with plant recoveries around $60-70 \%$ respectively. A chemical-mineralogical characterization by size fractions, XRF and XRD was carried out to implement a size classification stage in the processing plant. The finest fractions, containing higher grades of well liberated $\mathrm{Sn}, \mathrm{Ta}, \mathrm{Nb}$ minerals, were the feeding for dry high intensity magnetic separation (DHIMS) multifactorial tests, while, coarse fractions were re-grinded to maximize performance. The good results obtained in these tests demonstrate that two products with commercial quality could be obtained, a cassiterite concentrate with grades between $70-78 \% \mathrm{SnO}_{2}$ and a tantalite-columbite concentrate with grades ranging between 12 and $14 \% \mathrm{Ta}_{2} \mathrm{O}_{5}$ and $\mathrm{Nb}_{2} \mathrm{O}_{5}$, also increasing the overall recovery of the plant.
\end{abstract}

Keywords: high intensity magnetic separation; $\mathrm{Sn}-\mathrm{Ta}-\mathrm{Nb}$; critical raw materials; Penouta mine.

\section{Introduction}

The modern and competitive economy relies heavily on a range of critical raw materials owing to the risk in their supply and their economic importance [1,2]. Among these critical raw materials are $\mathrm{Ta}$ and $\mathrm{Nb}$, with significant applications in the technological and aeronautical fields [3]. These elements are mainly contained in minerals such as columbite and tantalite, which come mainly from the mines of Brazil and Central Africa respectively [2]. These mines are frequently managed by armed groups in conflict areas, so that commercialization of $\mathrm{Ta}$ and $\mathrm{Nb}$ as well as their forming minerals are regulated to avoid minerals of illegal mines to enter into the supply chain [4]. In order to reduce dependence on imports of $\mathrm{Ta}$ and $\mathrm{Nb}$ in Europe, it is necessary to increase the investigation of deposits that contain these elements and the processes for their concentration in Europe, within the framework of the Circular Economy [5]. 
The Penouta mine (Orense, Galicia) is the only active mine in Europe that produces concentrates of $\mathrm{Sn}, \mathrm{Ta}$ and $\mathrm{Nb}$ as main products, from the exploitation of the old tailings ponds and dumps by Strategic Minerals Spain (SMS) $[6,7,8]$. The industrial processing flowsheet is based on a grindingclassification stage, multiple stages of gravimetric concentration such as a battery of spirals and shaking tables, followed by a low intensity magnetic separation to reduce ferromagnetic impurities such as iron oxides. A primary concentrate of $\mathrm{Sn}-\mathrm{Ta}-\mathrm{Nb}$ is obtained as a product, with grades between $35-45 \% \mathrm{Sn}$ and $4-7 \% \mathrm{Ta}_{2} \mathrm{O}_{5}$ and $\mathrm{Nb}_{2} \mathrm{O}_{5}$, and plant recoveries around $60-70 \%$ respectively.

This study aims the chemical-mineralogical characterization by size fractions of the $\mathrm{Sn}$, Ta and $\mathrm{Nb}$ primary concentrate to study the feasibility of continuing their mineral processing by carrying out operations such as classification by circular vibrating screen and dry high intensity magnetic separation (DHIMS, hereinafter) multifactorial tests. The objective is to explore the possibility of obtaining independent concentrates of $\mathrm{Sn}$ and $\mathrm{Ta}-\mathrm{Nb}$ that could be commercially more competitive, thus contributing to increase grades and the overall recovery at the industrial plant of the Penouta mine.

\section{Material and methods}

A representative sample of the $\mathrm{Sn}-\mathrm{Ta}-\mathrm{Nb}$ primary concentrate from the Penouta mine were taken to carry out these tests, characterizing chemically and mineralogically by size fraction through sieving and X-ray Fluorescence (XRF, hereinafter) using a Bruker $4 \mathrm{~kW}$ set up in the ALS laboratory of the Penouta mine. Three size fractions were obtained, $>150 ; 150 / 90$ and $<90 \mu \mathrm{m}$. Fractions 150/90 and $<90 \mu \mathrm{m}$ were used for the DHIMS multifactorial assays. The fraction $>150 \mu \mathrm{m}$ was regrinded in order to achieve maximum yields of $\mathrm{Sn}, \mathrm{Ta}$ and $\mathrm{Nb}$.

DHIMS multifactorial tests were developed using a Felemamg laboratory-scale induced rotor high intensity magnetic separator (Figure 1) at Felemamg facilities in Gijón, Spain.

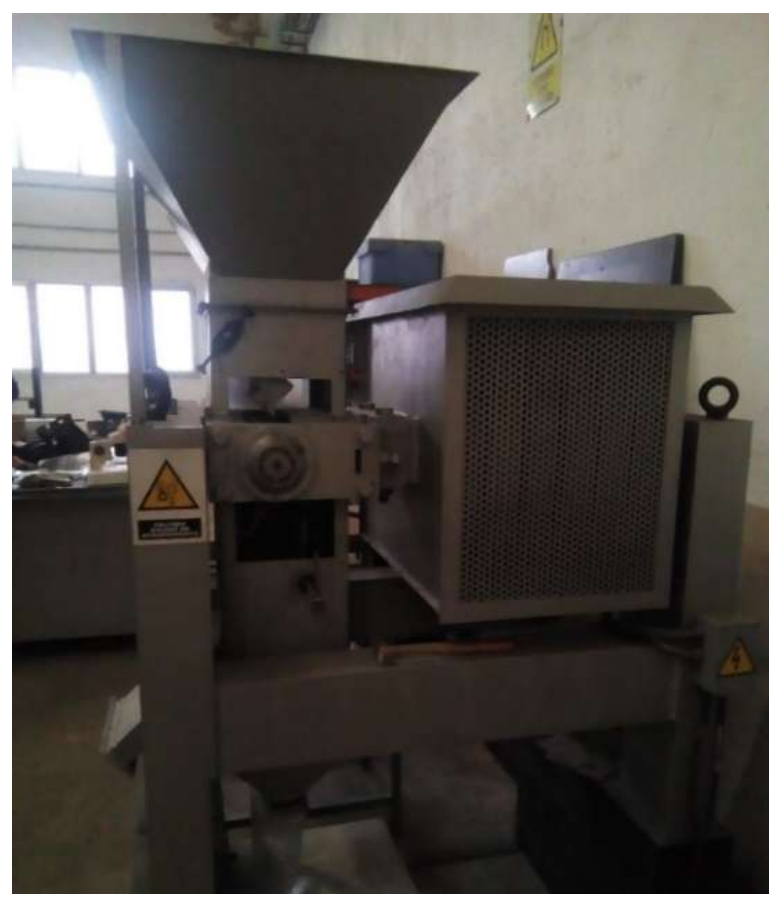

Figure 1 - Induced rotor high intensity magnetic separator. Felemamg facilities in Gijón, Asturias, Spain.

Table 1 shows the operational variables studied by size fractions for the DHIMS tests works. The intensity of the magnetic field was varied, changing the intensity (A) of the electric field, where the maximum intensity is $21,000 \mathrm{G}$. Subsequently, the non-magnetic products resulting from all the tests were reprocessed again with the DHIMS in order to simulate an industrial equipment with two induced rotors. A first test work with a wide granulometry $(150 / 0 \mu \mathrm{m}$, test 1 showed in Table 1$)$ was carried out; five test works with the $150 / 90 \mu \mathrm{m}$ fraction (tests 2-6) and another five test works with 
the $<90 \mu \mathrm{m}$ fraction (tests 7-11). Each product obtained, magnetic and non-magnetic, was analysed by XRF to know the grades and yields for the mineral species of interest, thus evaluating the feasibility of implementing a high intensity magnetic separator on an industrial scale in the Penouta mine. Besides, the phase compositions were characterized by X-ray Diffraction analysis (XRD, hereinafter) using a Siemens D5000 (Siemens, Berlin, Germany) apparatus and quantified by the Rietveld method on the tantalite-columbite concentrate $<90 \mu \mathrm{m}$ obtained, in order to identify mineral phases that could be responsible for decreasing grades of $\mathrm{Ta}$ and $\mathrm{Nb}$, and then to study the possibility of continuing its processing.

Table 1 - DHIMS assays configuration. Due to SMS data protection, they are considered qualitatively.

\begin{tabular}{cccc}
\hline Test No & Size fraction $(\boldsymbol{\mu m})$ & $\begin{array}{c}\text { Magnetic field intensity } \\
\text { (A) }\end{array}$ & Roll speed (rpm) \\
\hline 1 & $150 / 0$ & Low & High \\
2 & $150 / 90$ & Low & High \\
3 & $150 / 90$ & High & High \\
4 & $150 / 90$ & High & Low \\
5 & $150 / 90$ & Low & Low \\
6 & $150 / 90$ & Changing split inclination \\
7 & $90 / 0$ & Low & High \\
8 & $90 / 0$ & High & High \\
9 & $90 / 0$ & High & Low \\
10 & $90 / 0$ & Low & Low \\
11 & $90 / 0$ & Changing split inclination \\
\hline
\end{tabular}

Afterwards, representative samples of the fraction $>150 \mu \mathrm{m}$ of the primary concentrate were prepared to carry out the regrinding test works in a $0.18 \mathrm{~m}$ diameter mill, 4.51 capacity, charged with $7 \mathrm{~kg}$ of balls, resulting in $20.74 \%$ filling of balls (156 balls of $19.06 \mathrm{~mm}$ and 42 balls of $29.72 \mathrm{~mm}$ ); 1020 $\mathrm{g}$ of mineral for $9.3 \%$ mineral filling and $75 \%$ critical speed $(80.23 \mathrm{rpm})$. Subsequently, the grinded products were chemically and mineralogically analysed by size fraction after five different milling times: $0.5,2.5,5,10$ and $15 \mathrm{~min}$, throughout sieving and XRF analysis, respectively. Finally, the evolution of the percentage passing through the $100 \mu \mathrm{m}$ mesh was studied with respect to time, as this is the liberation size of tantalite $[9,10,11]$, as well as the distribution of the minerals of interest.

\section{Results and discussion}

3.1. Characterization and classification of the $\mathrm{Sn}, \mathrm{Ta}$ and $\mathrm{Nb}$ primary concentrate.

The results obtained from the assay by size study, as well as the metallic distribution of the elements of interest for the $\mathrm{Sn}, \mathrm{Ta}$ and $\mathrm{Nb}$ primary concentrate, are reported in Table 2.

This primary concentrate shows a D80 of $99 \mu \mathrm{m}$. The calculated feed grades were $33.75 \% \mathrm{Sn}$, $5.24 \% \mathrm{Ta}$ and $4.64 \% \mathrm{Nb}$, with significant $\mathrm{MnO}, \mathrm{Fe}_{2} \mathrm{O}_{3}$ and $\mathrm{SiO}_{2}$ contents . It can be noted that $\mathrm{Sn}, \mathrm{Ta}$, $\mathrm{Nb}$ contents increase with decreasing particle size, so that the highest concentration of these metals are found below $106 \mu \mathrm{m}$; on the contrary, $\mathrm{MnO}, \mathrm{Fe}_{2} \mathrm{O}_{3}, \mathrm{SiO}_{2}, \mathrm{MgO}$ are commonly concentrated in coarser fractions, according to the findings of $[10,11]$. In order to try to remove these impurities as much as possible from the coarser fractions prior to carrying out the magnetic separation test works, a vibrating circular sieve was used, throughout 150 and $90 \mu \mathrm{m}$ meshes (Figure 2), thus obtaining three size fractions: $>150,150 / 90$ and $<90 \mu \mathrm{m}$. The two finest factions $(150 / 90$ and $<90 \mu \mathrm{m})$ would be the feed for the DHIMS multifactorial test works, while the fraction $>150 \mu \mathrm{m}$ would be regrinded. 
Table 2 - Assay by size of Sn, Ta and Nb primary concentrate from the Penouta mine.

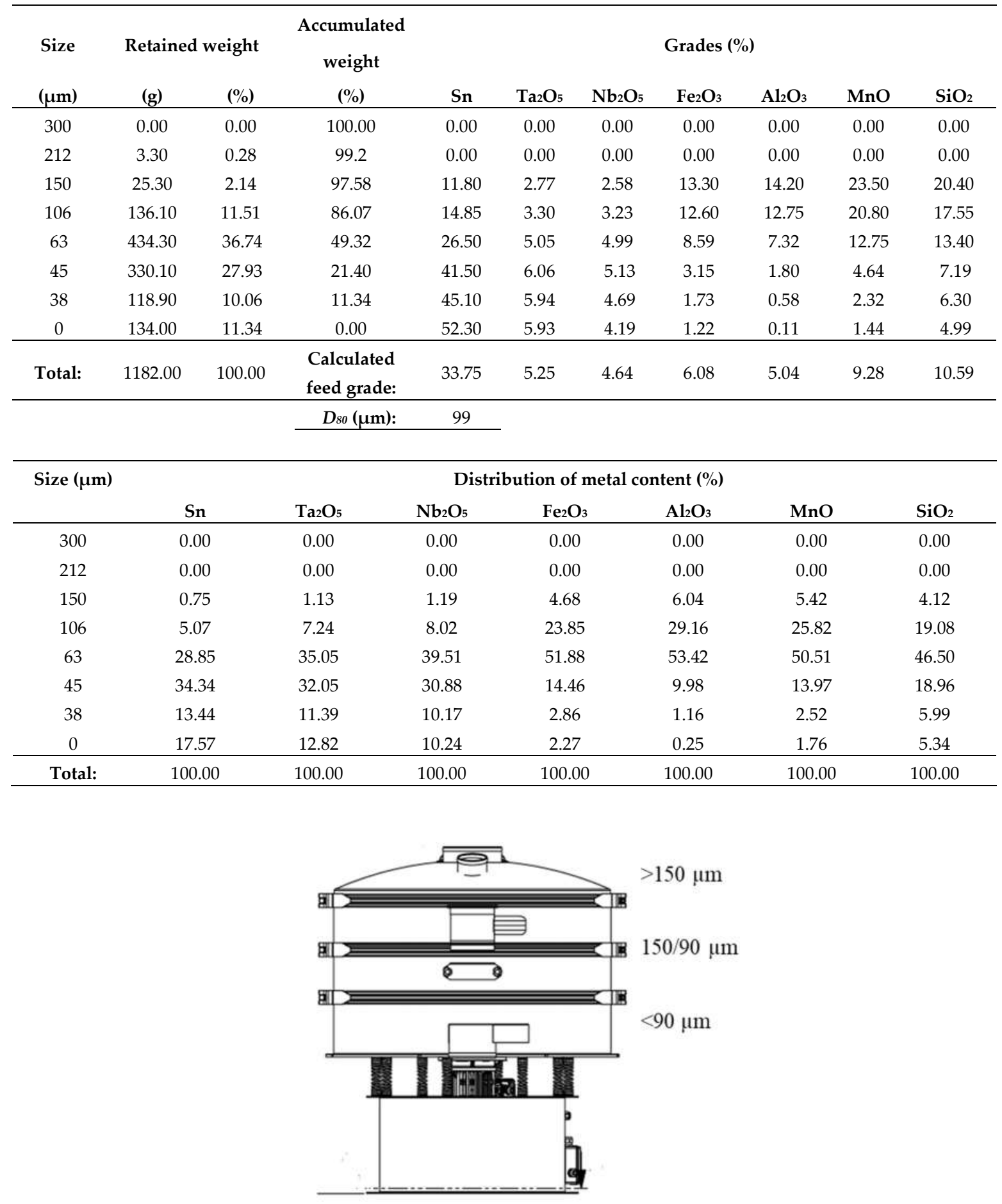

Figure 2 - Scheme of the vibrating circular sieve used to obtain three size fractions: $>150,150 / 90$ and $<90 \mu \mathrm{m}$.

\subsection{Results of laboratory scale DHIMS multifactorial test works}

\subsubsection{Grades and recoveries of the new concentrates obtained.}

The fractions 150/90 and $<90 \mu \mathrm{m}$ obtained in the previous classification stage were selected for the DHIMS multifactorial test works. Two products are obtained after DHIMS performance, a magnetic concentrate of columbo-tantalite and a non-magnetic concentrate of cassiterite, grades and recoveries are reported in Table 3 and Table 4, respectively, for each fractions and variables considered in Table 1. 
Table 3 shows that the best grades of $\mathrm{Ta}_{2} \mathrm{O}_{5}$ and $\mathrm{Nb}_{2} \mathrm{O}_{5}$ in the tantalite-columbite concentrate were obtained with test work \#6 for the $150 / 90 \mu \mathrm{m}$ fraction, reaching grades of $11.71 \% \mathrm{Ta}_{2} \mathrm{O}_{5}$ and $12.21 \%$ $\mathrm{Nb}_{2} \mathrm{O}_{5}$; while, test work \#7 was the best configuration for the $<90 \mu \mathrm{m}$ fraction, overtaking grades of $13.66 \% \mathrm{Ta}_{2} \mathrm{O}_{5}$ and $13.21 \% \mathrm{Nb}_{2} \mathrm{O}_{5}$. Specifically, test work \#7 supposed a better $\mathrm{Ta}_{2} \mathrm{O}_{5}$ grade even than $\# 1$, carried out with a wider size $150 / 0 \mu \mathrm{m}$.

Table 3 - Tantalite-columbite concentrate yields resulting from DHIMS test works. G: grades; R: recovery.

\begin{tabular}{|c|c|c|c|c|c|c|c|c|c|c|c|c|}
\hline \multirow{3}{*}{$\begin{array}{l}\text { Mineral } \\
\text { Test } \mathrm{n}^{\mathrm{O}}\end{array}$} & \multicolumn{2}{|c|}{$\mathrm{Ta}_{2} \mathrm{O}_{5}$} & \multicolumn{2}{|c|}{$\mathrm{SnO}_{2}$} & \multicolumn{2}{|c|}{$\mathrm{Nb}_{2} \mathrm{O}_{5}$} & \multicolumn{2}{|c|}{$\mathrm{SiO}_{2}$} & \multicolumn{2}{|c|}{$\mathrm{Fe}_{2} \mathrm{O}_{3}$} & \multicolumn{2}{|c|}{$\mathrm{MnO}$} \\
\hline & G & $\mathbf{R}$ & G & $\mathbf{R}$ & G & $\mathbf{R}$ & G & $\mathbf{R}$ & G & $\mathbf{R}$ & G & $\mathbf{R}$ \\
\hline & \multicolumn{2}{|c|}{$(\%)$} & \multicolumn{2}{|c|}{$(\%)$} & \multicolumn{2}{|c|}{$(\%)$} & \multicolumn{2}{|c|}{$(\%)$} & \multicolumn{2}{|c|}{$(\%)$} & \multicolumn{2}{|c|}{$(\%)$} \\
\hline 1 & 12.20 & 57.62 & 7.10 & 2.95 & 12.65 & 76.76 & 8.97 & 30.87 & 8.74 & 65.87 & 12.71 & 79.18 \\
\hline 2 & 10.33 & 68.18 & 3.34 & 2.09 & 11.10 & 89.39 & 13.44 & 52.81 & 12.01 & 83.44 & 17.36 & 96.14 \\
\hline 3 & 10.15 & 68.09 & 3.33 & 2.11 & 11.02 & 88.59 & 13.83 & 55.02 & 12.13 & 83.38 & 17.51 & 95.22 \\
\hline 4 & 8.80 & 69.82 & 26.99 & 19.18 & 8.79 & 85.61 & 9.41 & 49.87 & 7.62 & 78.34 & 10.84 & 89.55 \\
\hline 5 & 8.79 & 68.96 & 28.09 & 19.82 & 8.78 & 85.97 & 9.31 & 50.78 & 7.50 & 78.38 & 10.66 & 90.97 \\
\hline 6 & 11.71 & 70.11 & 7.29 & 3.87 & 12.21 & 91.88 & 10.13 & 42.86 & 9.47 & 80.89 & 13.86 & 97.86 \\
\hline 7 & 13.66 & 67.78 & 10.09 & 4.23 & 13.21 & 89.42 & 6.30 & 25.49 & 6.83 & 71.40 & 10.04 & 92.31 \\
\hline 8 & 13.47 & 67.80 & 10.77 & 4.61 & 13.61 & 90.95 & 6.15 & 24.76 & 6.65 & 70.24 & 9.75 & 91.11 \\
\hline 9 & 8.89 & 76.07 & 39.01 & 28.59 & 8.23 & 91.63 & 5.47 & 36.89 & 4.37 & 76.75 & 6.01 & 94.01 \\
\hline 10 & 9.03 & 76.34 & 37.93 & 26.69 & 8.42 & 94.08 & 5.38 & 35.81 & 4.38 & 77.93 & 6.03 & 95.78 \\
\hline 11 & 13.13 & 68.24 & 13.65 & 5.93 & 13.24 & 91.15 & 5.36 & 22.51 & 5.89 & 69.52 & 8.69 & 90.58 \\
\hline
\end{tabular}

Table 4 - Cassiterite concentrate yields resulting from DHIMS test works. G: grades; R: recovery.

\begin{tabular}{|c|c|c|c|c|c|c|c|c|c|c|c|c|}
\hline \multirow{3}{*}{$\begin{array}{l}\text { Mineral } \\
\text { Test } \mathbf{n}^{\mathbf{0}}\end{array}$} & \multicolumn{2}{|c|}{$\mathrm{Ta}_{2} \mathrm{O}_{5}$} & \multicolumn{2}{|c|}{$\mathrm{SnO}_{2}$} & \multicolumn{2}{|c|}{$\mathrm{Nb}_{2} \mathrm{O}_{5}$} & \multicolumn{2}{|c|}{$\mathrm{SiO}_{2}$} & \multicolumn{2}{|c|}{$\mathrm{Fe}_{2} \mathrm{O}_{3}$} & \multicolumn{2}{|c|}{$\mathrm{MnO}$} \\
\hline & G & $\mathbf{R}$ & G & $\mathbf{R}$ & G & $\mathbf{R}$ & G & $\mathbf{R}$ & G & $\mathbf{R}$ & G & $\mathbf{R}$ \\
\hline & \multicolumn{2}{|c|}{$(\%)$} & \multicolumn{2}{|c|}{$(\%)$} & \multicolumn{2}{|c|}{$(\%)$} & \multicolumn{2}{|c|}{$(\%)$} & \multicolumn{2}{|c|}{$(\%)$} & \multicolumn{2}{|c|}{$(\%)$} \\
\hline 1 & 1.84 & 27.12 & 75.06 & 97.51 & 0.41 & 7.78 & 6.56 & 70.89 & 0.62 & 14.61 & 0.13 & 2.53 \\
\hline 2 & 2.01 & 26.37 & 75.57 & 93.73 & 0.58 & 9.25 & 6.36 & 49.62 & 0.84 & 11.59 & 0.29 & 3.19 \\
\hline 3 & 1.95 & 25.00 & 76.96 & 93.40 & 0.49 & 7.50 & 6.34 & 48.28 & 0.72 & 9.47 & 0.21 & 2.19 \\
\hline 4 & 2.13 & 24.93 & 73.91 & 77.48 & 0.78 & 11.18 & 6.56 & 51.28 & 0.88 & 13.35 & 0.51 & 6.21 \\
\hline 5 & 2.15 & 25.13 & 73.91 & 77.61 & 0.80 & 11.67 & 6.58 & 53.42 & 0.86 & 13.37 & 0.52 & 6.61 \\
\hline 6 & 1.89 & 25.76 & 78.23 & 94.39 & 0.41 & 7.07 & 6.27 & 60.37 & 0.61 & 11.86 & 0.12 & 1.93 \\
\hline 7 & 1.85 & 26.81 & 76.58 & 93.96 & 0.37 & 7.13 & 6.67 & 78.87 & 0.57 & 17.43 & 0.11 & 2.96 \\
\hline 8 & 1.85 & 26.93 & 77.34 & 95.57 & 0.38 & 7.26 & 6.70 & 77.81 & 0.58 & 17.67 & 0.11 & 2.97 \\
\hline 9 & 1.65 & 18.67 & 74.17 & 71.30 & 0.35 & 5.12 & 7.52 & 67.25 & 0.53 & 12.35 & 0.11 & 2.28 \\
\hline 10 & 1.65 & 19.17 & 74.68 & 72.33 & 0.34 & 5.21 & 7.63 & 69.90 & 0.54 & 13.23 & 0.10 & 2.19 \\
\hline 11 & 1.79 & 26.26 & 75.57 & 92.72 & 0.36 & 6.96 & 6.73 & 79.90 & 0.55 & 18.36 & 0.10 & 2.95 \\
\hline
\end{tabular}

Table 3 also shows that the best recoveries for the 150/90 $\mu \mathrm{m}$ fraction resulted from \#6, with $70.11 \%$ and $91.88 \%$ of $\mathrm{Ta}_{2} \mathrm{O}_{5}$ and $\mathrm{Nb}_{2} \mathrm{O}_{5}$, respectively; in contrast, $\# 10$, with recoveries of $76.34 \%$ and $94.08 \%$ of $\mathrm{Ta}_{2} \mathrm{O}_{5}$ and $\mathrm{Nb}_{2} \mathrm{O}_{5}$, respectively, was the best configuration for the $<90 \mu \mathrm{m}$ fraction. Such results are accordingly with the liberation size below $100 \mu \mathrm{m}$ reported for the tantalite $[9,10,11]$, thus demonstrating the influence of the size particle on the increase of the grades and the recoveries of the species. Furthermore, the fact of a higher content of $\mathrm{SiO}_{2}, \mathrm{Fe}_{2} \mathrm{O}_{3}$ and $\mathrm{MnO}$ in the tantalite-columbite concentrate in coarser granulometry stands out [12].

Regarding the non-magnetic cassiterite concentrate, the best grades and recoveries of $\mathrm{SnO}_{2}$ were obtained in $\# 6$ and $\# 8$ test works, for the $150 / 90$ and $<90 \mu \mathrm{m}$ fractions respectively, reaching grades of $78.23 \%$ and $77.34 \% \mathrm{SnO}_{2}$ and recoveries of $94.39 \%$ and $95.57 \% \mathrm{SnO}_{2}$, respectively (Table 4). Therefore, \#6 test work is considered the optimal configuration for the $150 / 90 \mu \mathrm{m}$ fraction, since it shows the best results for both grades and recoveries of $\mathrm{SnO}_{2}$ and $\mathrm{Ta}_{2} \mathrm{O}_{5}$. Whereas, the fraction $<90 \mu \mathrm{m}$ through the configuration of $\# 7$ shows the best results to favour the increase of $\mathrm{Ta}_{2} \mathrm{O}_{5}$ and $\mathrm{Nb}_{2} \mathrm{O}_{5}$ grades and one of the best for $\mathrm{SnO}_{2}$. 
The XRD pattern of the tantalite-columbite concentrate $<90 \mu \mathrm{m}$ (Figure 3) shows the presence of minerals such as xenotime, cassiterite, aluminum silicates of $\mathrm{Mn}$, goethite and zircon as main impurities associated with the predominant tantalite-columbite (Mn)[12]. These results complement the information obtained by XRF (Table 3), confirming that elements such as Mn and Fe are intrinsically associated with the mineralogy of tantalite-columbite, indeed. Consequently, their physical separation is impossible.

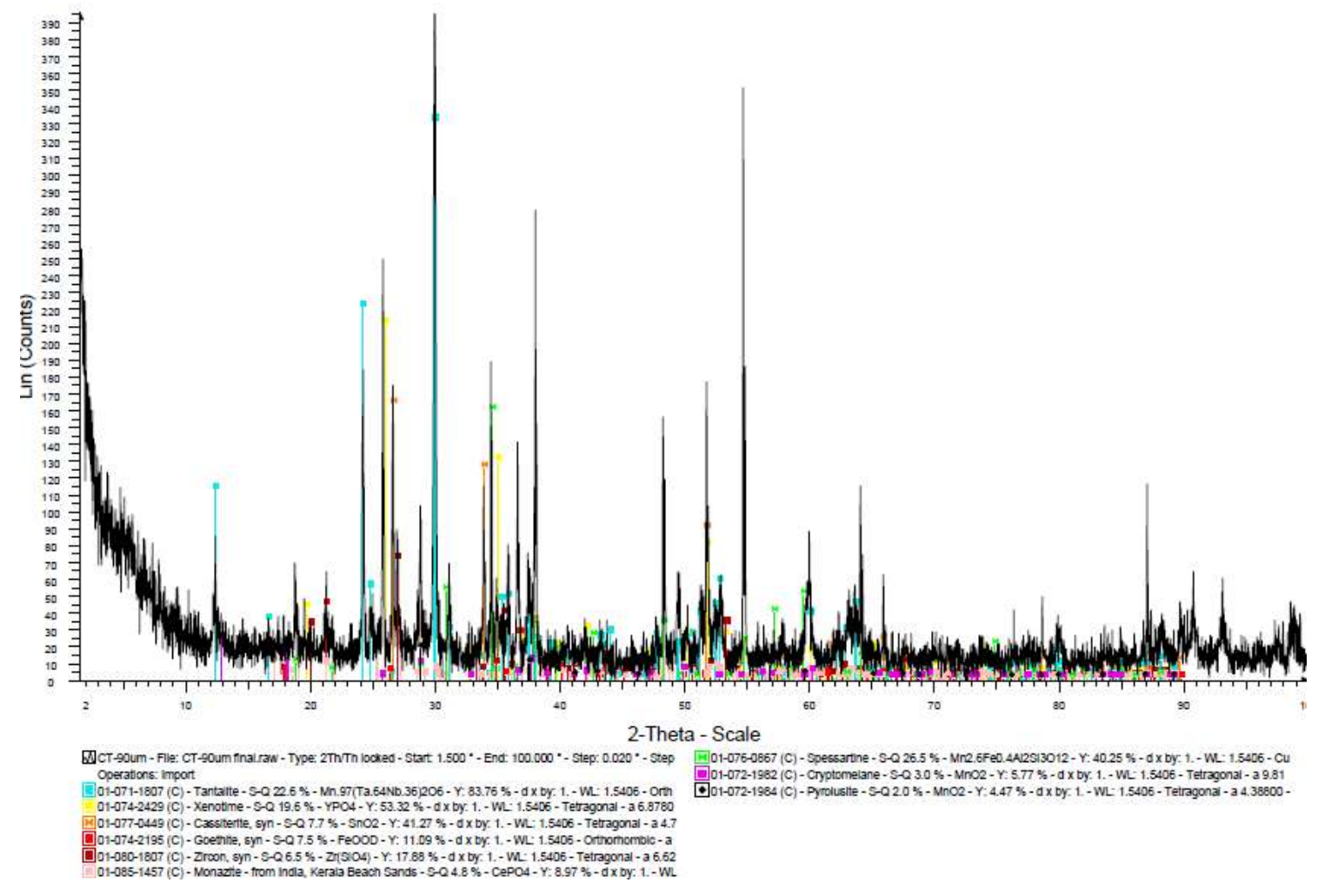

Figure 3 - XRD pattern of the tantalite-columbite concentrate sample $<90 \mu \mathrm{m}$.

\subsubsection{Influence of operational parameters in DHIMS test works.}

According to the results shown in Table 3-4, a higher roller speed seems to favour greater recoveries not only for the cassiterite in the non-magnetic product, but also for tantalite-columbite in the paramagnetic product obtaining good grades, as a better separation of the streams occurs, then allowing the adjustment of the split in order to increase the cassiterite grades in the non-magnetic product and recovery of tantalite in the magnetic product.

Regarding the intensity of the magnetic field, as the particle size is smaller a greater intensity is necessary than with a coarser granulometry for the same roller speed. Likewise, the results suggest that a finer particle size favours both the grades and the recovery of $\mathrm{Ta}_{2} \mathrm{O}_{5}$ and $\mathrm{SnO}_{2}$.

In summary, when the feed is classified in two fractions, the selectivity of the operation increases, obtaining better results than for larger size fractions such as $150 / 0 \mu \mathrm{m}$.

\subsection{Regrinding of $>150 \mu \mathrm{m}$ fraction.}

The assay by size of the resulting products passing the $100 \mu \mathrm{m}$ mesh, after regrinding of the $>150$ $\mu \mathrm{m}$ fraction for each grinding time $(0.5,2.5,5,10$ and $15 \mathrm{~min})$ are shown in Table 5 . 
Table 5 - Evolution of the $P_{80}$ with respect to time and assay by size results on the regrinded $>150 \mu m$ fraction.

\begin{tabular}{|c|c|c|c|c|c|c|c|c|c|}
\hline \multirow[t]{2}{*}{ Time (min) } & \multirow{2}{*}{$\begin{array}{l}\text { Pass weight through } \\
100 \mu \mathrm{m}(\%)\end{array}$} & \multirow{2}{*}{$\begin{array}{c}P_{80} \\
(\mu \mathrm{m})\end{array}$} & \multicolumn{7}{|c|}{ Distribution of metal content (\%) } \\
\hline & & & Sn & $\mathrm{Ta}_{2} \mathrm{O}_{5}$ & $\mathrm{Nb}_{2} \mathrm{O}_{5}$ & $\mathrm{Al}_{2} \mathrm{O}_{3}$ & $\mathrm{Fe}_{2} \mathrm{O}_{3}$ & $\mathrm{MnO}$ & $\mathrm{SiO}_{2}$ \\
\hline 0.5 & 11.20 & 218 & 26.26 & 21.07 & 20.44 & 5.59 & 7.45 & 5.45 & 7.13 \\
\hline 2.5 & 17.60 & 197 & 38.25 & 30.81 & 29.66 & 8.77 & 11.67 & 8.91 & 11.39 \\
\hline 5.00 & 22.40 & 192 & 43.74 & 36.57 & 34.43 & 12.93 & 16.53 & 13.13 & 15.60 \\
\hline 10.0 & 30.90 & 185 & 51.09 & 46.81 & 43.13 & 20.75 & 26.47 & 22.14 & 23.05 \\
\hline 15.00 & 32.90 & 184 & 50.39 & 47.47 & 43.93 & 24.44 & 29.89 & 25.54 & 26.49 \\
\hline
\end{tabular}

Table 5 shows that as grinding time increases, the amount of milled material passing through the $100 \mu \mathrm{m}$ mesh increases. The $P_{80}$ with respect to time highlights the little difference between 10 to 15 min, suggesting the optimum time as $10 \mathrm{~min}$ for grinding to avoid regrinding of fines and loss of energy efficiency. Besides, the distribution of the metal content in the species of interest of the milled product passing through the $100 \mu \mathrm{m}$ mesh after the milling time shows an increase, reaching a higher liberation of at least $50 \%$ in the species of interest such as $\mathrm{Sn}$, Ta and $\mathrm{Nb}$ after $10 \mathrm{~min}$.

\section{Conclusions}

From the present research it is concluded that by implementing a size classification, better grades and recoveries of $\mathrm{Sn}, \mathrm{Ta}$ and $\mathrm{Nb}$ are obtained when performing DHIMS instead of using a wide granulometric interval $(150 / 0 \mu \mathrm{m})$, since selectivity increases during operation. Consequently, a circular vibrating screen was implemented to generate three size fractions; the finest fractions (150/90 and $<90 \mu \mathrm{m})$ were used as the feed of DHIMS multifactorial test works; the coarsest fraction $(>150$ $\mu \mathrm{m})$ was regrinded in a closed-circuit ball mill installed at the Penouta mine plant.

The multifactorial DHIMS test works on the $\mathrm{Sn}$, Ta and $\mathrm{Nb}$ primary concentrate generated two new products, a magnetic columbo-tantalite concentrate and a non-magnetic cassiterite concentrate with better grades, being therefore rather commercially competitive, and then leading to better profitability and feasibility for the Penouta mine project. The results for this test works suggest that a finer particle size favours both the grade and the recovery of $\mathrm{Ta}_{2} \mathrm{O}_{5}, \mathrm{Nb}_{2} \mathrm{O}_{5}$ and $\mathrm{SnO}_{2}$, hence, it is key to keep control on the grinding-classification circuit; maintain the $D_{80}$ of the primary concentrate and a better liberation of the mineral species of interest, in order to reproduce the results obtained in the present investigation.

The present work proposes to conduct electrostatic separation multifactorial tests to cut down on minerals such as zircon, monazite and xenotime and to purify the paramagnetic and non-magnetic concentrates obtained; as well as passing the tantalite-columbite concentrate thorough the DHIMS to increase the grades of $\mathrm{Ta}_{2} \mathrm{O}_{5}$ and $\mathrm{Nb}_{2} \mathrm{O}_{5}$. Regarding the regrinding test works on the fraction $>150 \mu \mathrm{m}$, the optimum time was $10 \mathrm{~min}$ to obtain a well liberation for the mineral species of interest $\mathrm{Sn}$, Ta and $\mathrm{Nb}$.

Author Contributions: Conceptualization and carry out the experiments, JN.; methodology, JN.; formal analysis, JN. and TL; investigation, JN.; data curation, JN.; writing - original draft preparation, JN.; writing - review and editing, JN., TL. and JMA.; supervision, TL. and JMA. All authors have read and agreed to the published version of the manuscript.

Funding: This research was funded by "Oviedo Siembra Talento" Industrial Ph.D. grant from the Council of Oviedo, in coordination with the University of Oviedo.

Acknowledgments: The authors thank Strategic Minerals Spain, S.L. access to concentrates and Felemamg the use of its facilities and equipment to carry out these test works.

Conflicts of Interest: The authors declare no conflict of interest. 


\section{References}

1. European Commission. (2017). Study on the review of the list of Critical Raw Materials - Critical Raw Materials Factsheets. In European Commission (Issue June). https://doi.org/10.2873/876644

2. European Commission. (2020). Citical raw materials resilience; charting a path toward greater security and sustainability (COM(2020)474 final). https://doi.org/10.1017/CBO9781107415324.004

3. Roskill. (2020). Tantalum. Retrieved March 19, 2020, from Outlook to 2029, 15th Edition. https://roskill.com/market-report/tantalum/

4. Regulation (EU) 2017/821 of the European Parliament and of the Council, 19 Official Journal of the European Union 1 (2017).

5. European Commission. (2018). European Commission, Report on Critical Raw Materials and the Circular Economy (Magnus Gislev and Milan Groho (ed.)). European Commission. https://doi.org/10.2873/331561

6. García Polonio, F. (2015). El Interés Económico y Estratégico del Aprovechamiento de Metales Raros y Minerales Industriales Asociados, en el Marco Actuaal de la Minería Sostenible: La Mina de Penouta (Orense, España) [Universidad Politécnica de Madrid]. https://doi.org/http://oa.upm.es/42895/

7. Llorens González, T., Mateos Aquilino, V., \& García Polonio, F. (2019). La mina de Penouta, minería sostenible para el abastecimiento de $\mathrm{Ta} \& \mathrm{Nb}$ en Europa. Recursos Minerales Críticos. Seminario Sociedad Española Mineralogía, 12. http://www.ehu.eus/sem/revista/seminarios_m.htm

8. Blengini, G. ., Mathieux, F., Mancini, L., Nyberg, M., \& Viegas, H. . (2019). Recovery of critical and other raw materials from mining waste and landfills: State of play on existing practices. In European Union. https://doi.org/10.2760/494020

9. Llorens González, T., García Polonio, F., López Moro, F. J., Fernández Fernández, A., Sanz Contreras, J. L., \& Moro Benito, M. C. (2017). Tin-tantalum-niobium mineralization in the Penouta deposit (NW Spain): Textural features and mineral chemistry to unravel the genesis and evolution of cassiterite and columbite group minerals in a peraluminous system. Ore Geology Reviews, 81, 79-95. https://doi.org/10.1016/j.oregeorev.2016.10.034

10. Ghorbani, Y., Fitzpatrick, R., Kinchington, M., Rollinson, G., \& Hegarty, P. (2017). A process mineralogy approach to gravity concentration of tantalum bearing minerals. Minerals, 7(194), 23. https://doi.org/10.3390/min7100194

11. Alfonso, P., Hamid, S. A., Garcia-Valles, M., Llorens, T., López Moro, F. J., Tomasa, O., Calvo, D., Guasch, E., Anticoi, H., Oliva, J., Parcerisa, D., \& García Polonio, F. (2018). Textural and mineral-chemistry constraints on columbite-group minerals in the Penouta deposit: evidence from magmatic and fluid-related processes. Mineralogical Magazine, 82(S1), S199-S222. https://doi.org/10.1180/minmag.2017.081.107

12. López-Moro, F. J., García Polonio, F., Llorens González, T., Sanz Contreras, J. L., Fernández Fernández, A., \& Moro Benito, M. C. (2017). Ta and Sn concentration by muscovite fractionation and degassing in a lenslike granite body: The case study of the Penouta rare-metal albite granite (NW Spain). Ore Geology Reviews, 82, 10-30. https://doi.org/10.1016/j.oregeorev.2016.11.027.

(C) 2020 by the authors. Submitted for possible open access publication under the terms and conditions of the Creative Commons Attribution (CC BY) license (http://creativecommons.org/licenses/by/4.0/). 